\title{
Participation and public sector: a democratic challenge
}

\section{Participação e Setor Público: um desafio democrático}

\begin{abstract}
The last few decades have provided evidence on how governments at different scales are called upon to effectively respond to rapidly changing social, political and economic scenarios. Scientific community seems to have paid scarce attention to the analysis and understanding of bureaucratic changes linked to the enactment of new forms of interaction between political institutions and civil society. Participation of civil society can rely on either circumscribed or broad political projects involving and affecting the ways public sector formulates and delivers the public services. In this paper I take stock of the scientific debate concerning margins of reform in public sector through participatory processes. On the basis of my academic experience on and practice with participatory initiatives, my argument is that we need to foster new reflections on the ways public sector can achieve effective goals through participation.
\end{abstract}

Keywords: Participation. Public sector. Change. Reform.

\section{Resumo}

Nas últimas décadas, profundos questionamentos sobre as formas de responder eficazmente às mudanças sociais, políticas e econômicas, em nível global, têm estado ao centro do debate de muitos governos. Contudo, a comunidade científica tem contribuído limitadamente à análise e compreensão das transformações que novos mecanismos de interação entre instituições políticas e sociedade civil podem desencadear a nível burocrático. A participação da sociedade civil pode ser iniciada a partir de projetos políticos circunscritos ou decorrer de uma conceção mais abrangente de reforma na construção e prestação dos serviços públicos. Este estudo propõe-se a rever a literatura científica relacionada com as margens de mudança que os processos participativos podem instituir no setor público. Com base na minha experiência acadêmica e prática, com iniciativas de cariz participativo, o meu enfoque é sobre a necessidade de a ciência avançar com a reflexão sobre as formas pelas quais o setor público pode alcançar resultados eficazes por meio da participação.

Data de submissão: 11-09-2014

Data de aprovação: 18-09-2014

1 Postdoc researcher for the European Project MOPACT at the Institute of Social Sciences ICS (University of Lisbon); member of the Research Group SUSTAIN coordinated by João Ferrão at ICS; Professor of Social Sciences at the Catholic University of Viseu; expert adviser with the NGO In Loco for the participatory program Bip/Zip of the Municipality of Lisbon (2013 best practice by the International Observatory of Participatory Democracy). 


\section{Introduction}

Democratic systems worldwide are currently facing a highly complex historical moment since the progressive advancement of international agencies within new rules of financial market has profoundly transformed role and functions of the State. At the same time a growing disaffection towards political institutions has been followed by new claims for effective governance solutions at multiple scales. Social and political sciences have proved to be extremely sensitive and provided abundant contributions on the issue in the last few years. Notwithstanding little attention has been paid on the transformations that public sector is compelled to undertake when governments are either demanded or spontaneously decide to include new actors in processes of policymaking. Participation of civil society and stakeholders is actually revealing the importance of approaching this topic while pinpointing the set of possible transformations that administrative commitment may have towards the achievement of new processes and goals. This paper aims exactly to contribute to the debate concerning the role of participatory mechanisms for public sector and the opportunity to overcome narrow visions of change towards new public sector rationales.

Alongside the numerous reforms affecting the public sector in the last few decades, several schools of thought have made the interaction with social and economic actors a case in point. The need to reconfigure strict principles of bureaucracy differently highlighted by New Public Management, New Governance and New Public Service has prepared the ground for the enactment of numerous participatory processes worldwide. The institution of new arenas providing space and instruments for the coming together of multiple actors and interests has become a key phenomenon of participatory democracy and a response to the demands for more social inclusion and governance effectiveness. When focusing on general ways through which public sector has been working on participation, it is evident that the demarcation between political and administrative spheres shielding respective sources of power has become interestingly muddied. As a result, the formulation and implementation of public policies with new networks of social actors and economic agencies has actually questioned current organizational and cultural configurations of the public sector.

The support to processes and goals of democratic enhancement and effective management has simultane- ously demanded new internal connections at the organizational level and demonstrated to have great relevance in terms of changes on structures and cultures. On moving, destabilizing and changing the connections among internal units as well as between elected and career officials through the inclusion of new actors, participatory processes may foster new administrative reforms and own the great potential to encourage new rationales for public sector.

On this basis, the paper will first propose an overview on the relation between democratic regimes and public sector by focusing on the potential that democracy owns in developing new effective governance mechanisms. As confirmed by the numerous schools of thoughts that have been concerned with the reform of bureaucratic principles, the second section will exactly provide a vision on the ongoing debate. Multiple instances of societal change have growingly shown how public sector does represent a critical topic of current democratic systems. The third part of the paper will precisely deal with the issues concerning participatory mechanisms as new devices of inclusion of social and economic actors for the enhancement of democracy. The new horizons that participation aims to achieve in terms of processes and goals make it a conceptual gateway to think on new possible rationales for public sector. With this argument the paper concludes by shining a light on the opportunity to reconfigure organizational and cultural features of public sector through participation.

The literature reviewed along the paper will make reference to milestone concepts of social and political sciences as well as more recent contributions in the field of participatory studies. My academic career is currently placed within this field of investigation and the practice that I have had the opportunity to collect with participatory initiatives as researcher and expert advisor in the last few years, provide me with sufficient confidence to affirm that we need to make a step forward with participatory processes. We actually need to learn from both successes and failures of experiences worldwide and use this knowledge to promote broad changes of Public Sector as one of the most important democratic challenges of our times.

\section{Democracy and public sector}

Challenges for current democratic systems are inherently related to deep transformations in the rela- 
tionship between State and market, within State powers and among national and international bodies at different scales. States have been required to play new and complex functions of intermediation between national safety and international networks' instances. The new "rules of the game" show that on the one hand there is the necessity to keep established hierarchies of States and powers, while on the other hand, many emerging fields of activity attempt to transform established equilibriums worldwide. Some scholars have been clear in assessing the essential abdication of the post-modern State for globalized financial economy, resulting in the reduction of power redistribution and citizens' participation. International enterprises have assumed political power role by embodying whether executive, legislative and judiciary powers and, so, occupied the spaces of civil society (SANTOS, 2003; CROUCH, 2010; DELLA PORTA, 2011).

At the same time, the identification of the State with political power and the reduction of the role of the State have led to a progressive process of reduction of the concept of democracy as strictly concerned with the accomplishment of procedural and pragmatic aspects. Representative democracy has been assimilated with the rules of the electoral process and, in turn, "reversed" the relationship between citizens and public administration in terms of matching supply and demand. Social claims and demands have been increasingly framed using a technical and often cryptic language that have often turned social demands into a sort of independent variable to be treated by experts in back office (DE GAULEJAC; BONETTI; FRAISSE, 1995). This narrowing process has put democracy at the center of the political debate because, while becoming a "narrow" concept, democracy has also widened its frontiers of understanding and matched polysemous significances and signifiers. Despite the attempt to take advantage of a simplified version of the world, able to move, remove or even hide emerging social demands, the expansion and "self-celebration" of liberal democracy has in turn compelled society and scientists to reflect on the quality of existing democracies and what we define as democracy itself (DIAMOND; MORLINO, 2005; PRZEWORSKI, 2010).

Administrative structures, in taking together legislative and administrative functions, have been traditionally demanded to effectively implement public policies of democratic regimes. Public sector has been argued to be the guaranty for democratic systems to be equal and more committed to decreasing social asymmetries produced by market rationale (GALE; HUMMEL, 2003). Reforming processes have to be interpreted within the framework of the attempts of modernization of the State, market and business, as well as new societal claims and global financial pressures. Thinking of society as plural, new forms of distributing power and integrating civil society with an integrated political society, interactive and inclusive strategies have represented an instrument for the whole political system to recover legitimatization (BOBBIO, 1995; SIMONSEN, 2009). Numerous factors apparently outside the public administration field of action, such as political elections, protests, political parties, social conflicts, claims for civil rights and so on, condition the apparatus in terms of the relationship with citizenship, as well as in the internal functioning. In line with this, recent reform programs have often aimed at reexamining some democratic constitutive pillars within a new complex network of multi-scale and inter-institutional relations. In the last few decades the model of "welfare State", as clearly dividing administration and politics in order to implement policies in a neutral way, has been profoundly questioned (PETERS, 2001).

By considering contemporary public sector as the gathered systems wherein political and bureaucratic instances look for multiple "contacts", it is necessary to understand what types of interactions are needed to construct new effective measures. The understanding of public administration changes requires an examination of multi-level reforms and the ways in which they are borrowed and connected with both national and international frameworks and agencies (MAJONE, 1994). Reform processes have to be distinguished by proper forms of modernization involving organizational, institutional and cultural transformations, oriented by external and internal factors. Reforms are rather considered as outcomes of planned actions induced by contingent situations aimed at transforming public administration as structure managing societal changes in consistence with changing models of State (MOZZICAFREDDO; SALIS GOMES, 2011).

We understand as reforming processes represent possible responses through which public sector can be enabled to effectively change and govern changes. According to Rondinelli (2007), public administrations can be strengthened through constitutional, electoral, governance, administrative or civil service reforms. As regards 
the last three, they imply reforms delineating roles, responsibilities, and the relationships among different administrative levels in order to strengthen mechanisms for interactive and cooperative decision-making, by specifying hence the procedures of bureaucratic accountability and of judiciary maintenance. As specifically regards civil service systems, reforms can involve adjusting responsibilities and obligations of public employees, pay levels, recruitment procedures, incentives, training and career development rules, and ethical standards.

\section{The interactive turn of policymaking}

New private interests, instances of non-public intervention in financial activities and exigencies of reforming public administration have gradually altered the role of the State. The idea of reforming the State in terms of power redistribution started to become a more general claim from the 1990s onwards, and new governance instances highlighted how modernizing administration meant re-conceiving the proper role of the State in terms of democratic measures, civil society and human rights. Public, semi-private, private, and non-profit bodies as well as citizens, interest groups and enterprises, have come to be considered important as public sector actors and started compelling new political devices (RHODES, 1996; KOHLER-KOCH, 1998).

In this sense, the school of thought called "New Public Management" (NPM) has stressed the importance of decentralizing, deregulating and delegating high quotas of political power to administrative managers from 1980s on (OSBORNE; GAEBLER, 1992). Understanding bureaucracies as inherently nested within a complex network of political actors, and acknowledging that political choices become more and more endemic to administrations, bureaucracies have become a critical issue for the enhancement of democratic life. The series of NPM reforms worldwide were expected to increase the legitimacy of political systems through improving effectiveness and efficiency by means of interactive devices. However, NPM "client orientation" has often resulted in the transposition of commercial values concerning cost reduction and, in general, has emphasized the tendency to devalue both the constitutional and legal position of bureaucratic apparatuses, in favor of a model "managerialism" strictu sensu. At the same time, between the end of the 1980s and the beginning of the 1990s a general shift from the concept of 'government' to 'governance' has been identi- fied as a general trend in democratic systems (MARCH; OLSEN, 1995; UNDP, 1997; PETERS, 2001; KOOIMAN, 2003). From the prevalence of managerialist measures in NPM, the idea of governance concerns a model of interaction within and among the State - political and legal environment - civil society - social and political interaction - and the private sector - jobs and income (CHEEMA, 2007). In this sense, in the last two decades several countries in Europe have acknowledged the evidence of new social frameworks demanding interactive institutional designs for policymaking with political systems. As the OECD has put it:

[g]iven the complexity and scale of emerging governance challenges, governments cannot hope to design effective policy responses, nor to strengthen legitimacy and trust, without the input, ideas and insights of as wide a variety of citizens' voices as possible. Public engagement will increasingly be recognised as another lever of governance - and become part of the standard government toolkit of budgeting, regulatory, e-government and performance management tools (OECD, 2009, p. 17).

Therefore, when taking interactive forms of public service formulation and delivery into consideration, numerous variables have to be put under a new light. At the bottom of any innovative political initiative, public sector and policymaking devices come to be settled within specific scenarios. Starting from the essential reliance on agency theory of NPM, several scholars have claimed that the principal aim of public administration is effectiveness and not efficiency, for the latter is likely to produce social exclusion in concordance with like-market principles. The legitimization of new governance networks between formal authorities with both economic and social subjects was set up new potential scenarios for partnership and cooperation. As the public sector comes to be officially involved with both formal and informal networks, capacities and abilities of negotiation become surprisingly important skills. On the one hand, the emphasis on transparency and accessibility through structural changes in bureaucracy was aimed at getting closer administrative decisions to the citizens. On the other hand, the effort to make interaction between citizens and political systems easier has been sustained by local experiments of participatory democracy. Denhardt and Denhardt (2007) have emphasized the necessity to overcome narrow references to either political/legal or like-market principles and postulated the model of New Public Service (NPS) within 
the new governance trends. The authors argue that global context is demanding new forms of implementing public policies, so as to make them more responsive to the demands of the environment and stress the new role of the government in assuming the responsibility to coordinate new subjects and interests for the accomplishment of effective actions. Political systems are required to provide adequate space for interactive decision-making involving politicians, civil service systems and society. Bureaucrats, in extending the role of the democratic citizen, should assume new functions for policymaking processes, by aiding citizens and interest groups to articulate their points of view, their exigencies, and so match individual instances with shared responsibilities.

Through NPS public interest becomes the result of new interactive arenas, aiming to overtake the mere addition of interests, in order to create wide agreement. By assuming the role of facilitating and negotiating priorities through institutionalized devices, public administrations has been demanded to foster horizontal models of interaction for effective collaboration, by both downsizing strict hierarchical structures and reducing central decision centers in order to approximate government to local instances.

\section{The rationales of participation}

The interaction between actors not included in policymaking hitherto, puts a complex series of questions on the table that political sciences and public policy analysts have been compelled to explore in the last few years. The potential conflicts emerging from the multiplication of the interests at the stake could have numerous consequences as regards demands to be accomplished, legitimization to be improved, mechanisms of reciprocal control. Controversies, conflicts and agreements acquire specific meanings when connected to the correspondent institutional designs supplying new interactive processes. Such a perspective moves scientists to focus, not only on the ineluctable dynamicity of such processes, but also to shift their attention from political leadership towards the relationships in progress.

The history of participation is indissolubly framed within the transformations of the role of the State and, therefore, public sector. When the links between who governs and who is governed become weak, participation is likely to reflect and recover democratic inclusion and social justice. Numerous participatory initiatives and are- nas with civil society have been created at different scales worldwide in the last few years. The myth concerning the use of participation as a substitute of representative democracy mechanisms still reveals that such a topic needs to be further deepened. Participatory democracy has been conceived as a set of principles and practices aimed at complementing representative democracy, yet different from forms of direct democracy, such as petitions and referendums. Participatory democracy includes a wide range of experiences setting new spaces of legitimized deliberation between political institutions and civil society beyond the traditional adversary model of political debate. Consultative and co-decisional processes have framed new opportunities for civil society to have an influence over public policymaking. On requiring citizen expertise to integrate political and technical expertise, new frameworks of interaction between political and civic societies have demanded profound changes in policymaking rationales. In social and political sciences, scholars have been compelled to make sense of such a varied scenario where the very definition of participation has become a challenging work of analysis and reflection (ARNSTEIN, 1971; FARRINGTON et al., 1993; BOBBIO, 2006; FUNG, 2006; CORNWALL, 2008).

The origin of participation in policymaking is connected to the first experiences aimed to "reinvent" political systems in Latin America in the end of 1980s. The replacement of economic resources on behalf of social-justice-oriented investments has made participatory budgeting one of the most important phenomenon in the field of participation (AVRITZER; NAVARRO, 2003; ALLEGRETTI; HERZBERG, 2004; AVRITZER, 2006). When Europe has started to look at participation as a potential gateway to set up innovative devices for public policies' formulation and/or implementation, many States have assumed the opportunity to make it a device for citizenry trust recovery, less electoral abstention, and effective solutions within increasing uncertainty in complex transnational networks and multi-scale economic, financial and political pressures (SINTOMER; ALLEGRETTI, 2009). However, such a growing presence of participatory initiatives in policymaking has not always corresponded to focused analyses on public policies. The attention on new participatory devices has often shown a weak connection between the attention on effective mechanisms and tools with public sector ways of making public policies (BEHER, 2011). 
Several initiatives and actions have framed interactive policymaking experiences in the world, moving towards the strengthening of participation as a device to include disadvantaged social groups and modernize public sector (WB, 1994; UN, 2008). Stressing the role of participation in terms of both securing and creating rights, Gaventa and Barret (2010) have recently assessed on the basis of the analysis on 100 cases worldwide that citizen engagement has broadly led to improvements in "health, livelihoods and food, water, housing and urban services and education, usually through gaining increased government attention and responsiveness to issues that might have been previously ignored." (GAVENTA; BARRET, 2010, p. 36).

Forms of participatory democracy assume political systems' legitimacy as grounded on involving citizens, so as to facilitate understanding public choice-making and securing equal political measures. Still, questions, doubts and dilemmas surrounding the development of participatory democracy in terms of genuine inclusive initiatives as well as the fading borders with other conceptions of democracy, are currently animated issues of scientific debate (BAIOCCHI, 2001; COOKE; KATHARI, 2001).

The possible commitment to cooperate needed from political institutions, business bodies and civil societies, in order to mobilize resources intended for development, raises a complexity of demands. By defining problems, elaborating scenarios, deciding solutions, such processes are required to enact policies that deal with either collective issues or specific interests (HOWLETT; RAMESH, 1995). In holding tight to its mission to provide stable frameworks for interaction - by grounding actions on shared "institutionalized meanings" as a basis for interpretation of path dependent actions in correspondence with the generating systems (MARCH; OLSEN, 1989) - policymaking has widely become the junction point for different "systems of participatory action". When demanded to rethink goals of economical growth within scenarios of crisis, and simultaneously acknowledging the increasing complexity of collective and private matters, the term itself of public policy enlarges its boundaries. Public policy becomes a definition applied to actual practices of problem-solving and not merely to formally announced intentions of government, i.e. the overall agency of governments and governmental actions.

In this sense, participatory policymaking should not be understood as a phase or process that is strictly separate from political actions and providing mere technical assessment pre/post the political calculations of policymakers. It rather represents the political exercise where public sector is caught in the middle of the commitment on reshaping public policies in order to define and/or solve new problems on the tables of governments with civil society (BRYNER, 2008). Participatory policymaking could be seen as a by-product of the multiple understandings and narratives constructed by interest groups, policy constituencies and scholars working in competing disciplines, and citizens producing new potential frameworks for social problems. The chance to make different forms of knowledge, know-how and power encounter is to constitute spaces where it is not the "truth" to be claimed, but rather the most plausible action to be undertaken in specific situations. By restructuring the definition of the setting and of the problems to be debated, there is the possibility to create the conditions for more complex models of policymaking (FALANGA, 2013; FALANGA; ANTONINI, 2013).

This wider conception of participatory principles implementation leads to open complex questions. Are participatory processes capable of resolving dilemmas concerning problem setting of participation itself and setting up different interacting views of public administration? Do they enable actors to manage and resolve mutual interests (democratic aspects) at minimal transaction costs (efficacy and effectiveness) in stable frameworks (legality)? Will explicit discussion about public good bring to light contradictions and conflicts more disruptive than society is prepared to handle, or will it rather silence established interests in a tokenistic way? Under what conditions will policy stakeholders be likely to change their beliefs and their "myths"? And then, what sort of outcomes should we expect from participatory policymaking process? Could they effectively change equilibriums or would they rather become new myths used to cover up forms of the status quo?

\section{The challenging futures of public sector}

This final section seeks to gather a general response to the questions that participation stimulates through exploring to what extent participatory processes can represent a change towards a new public sector rationale. My point is that participation should be tackled as the chance for transition, rather than a goal per se of some vague public service enhancement.

The interaction with non-governmental actors for 
policymaking has been broadly interpreted as the biggest challenge for current democratic regimes (RHODES, 1996; SCHMIDT, 2006; PETERS; PIERRE, 2012). NPM and NPS have largely assumed new interactive settings as the starting point for new effective governmental actions. Understanding reforms as not only punctual experiments but rather "symbolically mediated change processes which can be understood only if we uncover the action-motivating reasons that guide efforts to alleviate practical problems" (DUNN, 2002, p. 259), the challenge of making participants interact and find a common objective as a result of their deliberations, also corresponds to the challenges of solving problems by integrating governing functions. Several studies have highlighted how reforms show the existing gap between normative directives and organizational behaviors. In this respect, for example, Brunnson and Olsen (1993) have stressed how reforms normally succeed as organizational discourse, but can have little impact on daily activities. Issuing reforms does not guarantee reforming processes: it is always possible to change without changing anything and create situations of "innovative immobilization" (THOMPSON, 1995). In other terms, changing public sector implies transforming organizations and promoting cultural patterns supporting new rationales (FALANGA, 2013). Said so, participation may play a positive perturbing role aimed at establishing some degree of positive confusion in the "organizational chart": which roles, which functions, which relations are supposed to govern effective interaction with new actors of policymaking?

The question is crucial, inasmuch as it reveals what type and degree of change is conceived in terms of public sector. If one of the critical points has been the bureaucratic segmentation of the problems to be tackled through "sectorialized" policymaking, participatory processes potentially require and can provide a more integrated vision of the territory because of the introduction of complexity as a "new public sector rationale". The emergence of new participatory devices might be regarded as the creation of a different institutional environment, which can possibly change the structure and cultures of political systems and its office holders. Towards this aim, it is necessary to understand what administrative reforms rely on, whether on the (good) willingness of some administrative personnel or on a complex effort at reframing public service. Either reforms rely on the kind of confidence revealing the never-ending bureaucratic ideal of well-conformed bureaucrats, or they are committed rather to work through the impact, resources and limits of reforms at the structural and symbolical level. This compels science to take into consideration the political intentions "starting up" administrative reforms, and the possibility of tackling "easy" changes inspired by managerial ambitions or reforms, inspired by the complex nature of public sector, its mechanisms, devices and structure. Participatory processes demand the (re)organization of administrative levels, systems and connections in order to sustain their implementation.

The point is not to imagine new models of organization, but rather to make the vertical and horizontal ways of working consistent with the new exigencies of effectiveness demanded by new policymaking. The change does not rely on the organizational chart (and its reproduction), but on new agreements between representative elected officials and administrative units. The necessity to check competences and possible connections implies "meta-working" on the proper State rationale demanded to play a different role with society. Therefore, general reforms of public sector have to be interpreted in connection with the attempts of modernization in response to local and global claims and pressures. At the level of design and implementation, we should look at the forms in which participatory processes are conceived in connection with the whole administrative architecture, as well as at the ways they either produce new models of work or reproduce "familiar" schemes. In these terms, we should also pay attention to the ways political institutions normatively frame participatory processes: what degrees of flexibility and margins of maneuver are provided for interaction and decision-making? Participation implies making political and administrative actors open a space for negotiation and reformulation of identities, interests and objectives. When we understand how participation is worked we can understand where participation is placed in the mind of the political institution and how administrative staffs redefine their commitment and performance towards its enactment.

\section{Conclusive reflections}

The paper has made a first point on the debate concerning possibilities of reforming public sector through participation. I have first argued that representative democracy is facing a controversial historical moment related to the narrow attempts to make coincide first the State with political systems and then the model 
of representative democracy with its procedural mechanisms. Current demands for new effective devices able to respond to multi-level problems compel understanding how complex networks of agencies can be included into more effective policymaking. For this reason I have focused on public sector as needing adequate reforms when managing new interactive forms of public decision and/ or implementation. I have connected the development of participatory processes in correspondence with two of the principal schools of thought in the field of public administration reforms, NPM and NPS that have opened to new interactive forms of policy formulation and delivery. In this line, I have stressed that regulatory bureaucracies should structure new degrees of flexibility and accountability when implementing participatory processes, as well as that different models of public organizations should sustain the administrative work transforming the connection among units and between elected and career officials towards new broad participatory rationales. My argument is thus related to the necessity to make a step forward with participation: it needs to become an organic impulse for public sector reforms in order to turn the success of single practices into the success of effective governance systems.

\section{References}

ALLEGRETTI, Giovanni; HERZBERG, Carsten. El 'retorno de las carabelas': los presupuestos participativos de América Latina en el contexto europeu. Transnational Institute y Fundación de Investigaciones Marxistas, Amsterdam, v. 5, n. 4, p.1-28, 2004.

ARNSTEIN, Sherry. A ladder of citizen participation. Journal of the Royal Town Planning Institute, London, v. 57, n. 4, p. 176-182, 1971.

AVRITZER, Leonardo. New public spheres in Brazil: local democracy and deliberative politics. International Journal of Urban and Regional Research, v. 30, n. 3, p. 62337, Oct. 2006.

AVRITZER, Leonardo; NAVARRO, Zander (Ed.) A inovação democrática no Brasil. São Paulo: Cortez, 2003.

BAIOCCHI, Gianpaolo. Participation, activism, and politics: the Porto Alegre experiment and deliberative democratic theory. Politics \& Society, London, v. 29, n. 1, p. 43-72, Mar. 2001.

BEHRER, Laurence. Les relations ambiguës entre participation et politiques publiques. Participations, Paris, v. 1, n. 1, p.105-133, Jan. 2011.
BOBBIO, Luigi. Dilemmi della democrazia partecipativa. Democrazia e Diritto, Milan, n. 4, p.7-26, Oct. 2006.

BOBBIO, Norberto. Stato, governo, società. Turin: Einaudi, $1995 / 1985$.

BRUNSSON, Nils; OLSEN, Johan P. The Reforming organization. London: Routledge, 1993.

BRYNER, Gary C. Public Organizations and public policies. In: PETERS, Guy B.; PIERRE, Jon (Ed.) Handbook of public administration. London: SAGE, 2008. p. 189-198.

CHEEMA, Shabbir. Linking governments and citizens through democratic governance. In: UN 7th Global Forum on Reinventing Government Building Trust in Government. Public Administration and democratic governance: Governments Serving Citizens. Vienna: Austria, 2007. p. 29-51.

COOKE, Bill; KOTHARI, Uma. Participation: the new tyranny? London/New York: Zed Books, 2001.

CORNWALL, Andrea. Unpacking 'Participation': models, meanings and practices. Community Development Journal, Oxford, v. 43, n. 3, p. 269-283, June 2008.

CROUCH, Colin. Democracy and the economy. In: PIZZORNO, Alessandro (Ed.) La democrazia di fronte allo stato democratico. Milan: Feltrinelli, 2010. p. 181-192.

DE GAULEJAC, Vincent; BONETTI, Michel; FRAISSE, Jean. L'ingénerie sociale. Paris: Alternatives Sociales Syros, 1995.

DELLA PORTA, Donatella. Democrazie. Bologna: Il Mulino, 2011.

DENHARDT, Robert B.; DENHARDT, Janet V. The New Public Service: serving, not steering. New York/London: M.E. Sharpe, 2007.

DIAMOND, Larry J.; MORLINO, Leonardo. Assessing the Quality of Democracy. Baltimore: The Johns Hopkins University Press, 2005.

DUNN, William N. Policy Reforms as Arguments. In: FISCHER, Frank; FORESTER, John (Ed.) The Argumentative Turn in Policy Analysis and Planning. Taylor \& Francis e-Library, 2002. p. 254-290.

FALANGA, Roberto. Developing Change. A Psychosociological action research with Civil Servants engaged in Participatory Processes, PhD Thesis University of Coimbra, 2013. Available on: <https://estudogeral.sib.uc.pt/handle/10316/24148>. Access on: 01 July 2014. 
FALANGA, Roberto; ANTONINI, Matteo. Transforming cities, societies and policies. Psychological reflections on participatory processes' experiences. CES Contexto Debates: Rethinking Urban Inclusion Spaces, Mobilizations, Interventions, Coimbra, n. 2, p. 572-587, June 2013.

FARRINGTON, John et al. Reluctant Partners: Non-governmental Organisations, the State and Sustainable Agricultural Development. London: Routledge, 1993.

FUNG, Archon. Varieties of Participation in Complex Governance. Public Administration Review Special Issue: Collaborative Public Management, Malden/Chichester/ Singapore, v. 66, n. S-1, p. 66-75, 2006.

GALE Scott A.; HUMMEL, Ralph P. A debt unpaid: Reinterpreting Max Weber on bureaucracy. Administrative Theory \& Praxis, New York, v. 25, n. 3, p. 409-18, Sept. 2003.

GAVENTA, John; BARRET, Gregory. So What differences does it make? mapping the outcomes of citizen engagement. Working Paper, Institute of Development Studies, Development research Centre Citizenship, Participation and Accountability, Brighton, v. 2010, n. 347, p. 1-72, Oct. 2010.

HOWLETT, Michael; RAMESH, M. Studying public policy: Policy cycles and Policy Subsystems. Oxford: Oxford University Press, 1995.

KOHLER-KOCH, Beate. A evolução e transformação da governação europeia. Análise Social, Lisbon, v. 23, n. 148, p. 659-684, July 1998.

KOOIMAN, Jan. Governing as governance. London: Sage Publications, 2003.

MAJONE, Giandomenico. The rise of the regulatory State in Europe. West European Politics, Oxford/New York, v. 17, n. 3, p. 77-101, May 1994.

MARCH, James G.; OLSEN, Johan P. Reforming Institutions: the organisational basis of politics. New York: Free Press, 1989.

MARCH, James G.; OLSEN, Johan P. Democratic governance. New York: Free Press, 1995.

MOZZICAFREDDO, Juan; SALIS GOMES, João (Ed.). Projectos de inovação na gestão publica. Lisbon: Mundos Sociais, 2011.

OECD. Focus on citizens: public engagement for better policy and services. Public governance and territorial development directorate, 2009. Available on: http://www. sourceoecd.org/governance/9789264048867. Access on: 06 June 2014.
OSBORNE, David; GAEBLER, Ted. Reinventing government: How the entrepreneurial spirit is transforming the public sector. Massachusetts: Addison-Wesley, 1992.

PETERS, Guy B. The Future of Governing. Lawrence: University Press of Kansas, 2001.

PETERS, Guy B.; PIERRE, Jon. Politicians, bureaucrats and administrative reform. London: Routledge, 2001.

PETERS, Guy B.; PIERRE, Jon. Introduction: The role of public administration in governing. In: PETERS, Guy B.; PIERRE, Jon (Ed.) The sage handbook of public administration. London: SAGE, 2012.

PRZEWORSKI, Adam. Democracy and the limits of self-government. Cambridge: Cambridge University Press, 2010.

RHODES, Raw A.W. The new governance: governing without governance. Political Studies, Oxford, v. 44, n. 4, p. 652-667, Dec. 1996.

RONDINELLI, Dennis. Governments serving people: the changing roles of public administration in democratic governance. In: UN 7th Global Forum on Reinventing Government Building Trust in Government: Public Administration and democratic governance: Governments Serving Citizens. Vienna: UN, 2007. p.1-28.

SANTOS, Boaventura Sousa (Ed.). Democratizar a democracia: os caminhos da democracia participativa. Porto: Afrontamento, 2003.

SCHMIDT, Vivien A. Democracy in Europe: the EU and national polities. New York: Oxford University Press, 2006.

SIMONSEN, Arne. And the winner is trust and credibility. In: OECD, Focus on citizens: public engagement for better policy and services. OECD, 2009. p.188-191.

SINTOMER, Yves; ALLEGRETTI, Giovanni. I bilanci partecipativi in Europa: Nuove esperienze Democratiche nel vecchio continente. Rome: Ediesse, 2009.

THOMPSON, John. Participatory approaches in government bureaucracies: facilitating the process of institutional change. World Development, Philadelphia, v. 15, n. 4, p.1521-1554, September 1995.

UNITED NATIONS. People matter: civic engagement in public governance. New York: UN, 2008. Available on: <http://unpan1.un.org/intradoc/groups/public/documents/un/unpan028608.pdf>. Access on: 29 July 2014. 
UNDP. Governance for Sustainable Human Development. New York: UNDP, 1997. Available on: <http://gis.emro. who.int/HealthSystemObservatory/Workshops/WorkshopDocuments/Reference\%20reading\%20material/ Literature\%20on\%20Governance/GOVERN 2.PDF>. Access on: 06 May 2014.

WORLD BANK. The World Bank and participation. success, constraints and responses. Washington: World Bank, 1994. Available on: <http://siteresources.worldbank.org/INTPCENG/Resources/sdp-29.pdf>. Access on: 12 Mar. 2014 